\title{
STATE INNOVATION POLICY FOR GREEN TECHNOLOGIES SUPPORT IN CONSTRUCTION
}

\author{
Liubov Zgalat-Lozynska'
}

\begin{abstract}
The purpose of the paper is to determine the status and areas of improvement of state policy to support the development of green technologies in construction. Methodology. This review is based on the characteristics of individual areas of implementation of green technologies in construction. Possibilities of using renewable sources in the process of construction and operation of buildings are considered. It is established that different methods of energy production are used in energy efficient houses. These include photovoltaic solar panels, heat pumps, photothermal collectors, geothermal waters, mini hydroelectric power plants. It is emphasized that the energy consumption of such buildings should also be reduced; for the reason of special architectural design solutions, the energy-efficient materials with high thermal insulation properties are used. The peculiarities of the policy of stimulating the increase of energy efficiency of buildings in Ukraine are considered, the conclusion on its insufficient efficiency is given. The reason for ineffectiveness of the incentive policy is figured out. The directions for reduction of air and water pollution by filtration and use of rain and melt water for household needs are considered. It is established that the active implementation of innovation is impossible mainly due to obsolete housing and worn-out utilities. Eco-design is also used to increase energy efficiency in construction and architects must actively use passive and active methods of designing houses in different climatic conditions. Green construction also involves recycling of construction waste. Improving the environmental efficiency of buildings and structures involves the use of modern insulation materials, coatings. Currently, nanomaterials with unique properties are becoming widespread in construction. They have increased physical characteristics, in particular, accumulated thermal radiation, provided significant energy savings in winter and summer. The results of the study showed that the state regulatory policy (innovation policy, support of science and $R \& D$, technology transfer, price policy regulation, updating of technological regulations) has an extremely important role in stimulating the spread of green technologies in construction. Practical implications. The most important areas of public policy in construction are: the implementation of environmental energy and quality international standards for construction products; stimulating consumer demand for environmentally friendly innovative solutions, including through "green" public procurement, setting reasonable prices for energy resources, stimulating the implementation of a holistic concept of product life cycle; development of financial mechanisms to support the demand for cleaner technologies and innovations.
\end{abstract}

Key words: green technologies, construction, energy efficient house, eco-design, state regulation.

JEL Classification: L16, L74, O31, O38, O39, Q28

\section{Introduction}

The usage of new technologies and materials in construction causes of increasing of the level of environmental end economic efficiency of the building structures installation and operation of construction sites. At the same time, in order to reduce energy resources costs and the economic crisis, the innovations in construction must reflect the modern requirements of consumers for energy efficiency and low cost of housing. Therefore, developers must produce high-quality product with

\footnotetext{
Corresponding author:

${ }^{1}$ Kyiv National University of Construction and Architecture, Ukraine. E-mail: zgalatlozynska@gmail.com ORCID: https://orcid.org/0000-0002-2063-5738
}

determined parameters, such as environmental safety, energy efficiency, new fashionable design, durability, economy. All these requirements can be met only with the application of new design solutions based on modern technological advances. However, construction is characterized by conservatism and inertia of the introduction and widespread use of new technologies. This inertia is primarily due to the duration of changes in technological regulations of construction for the introduction of innovative technologies and 
methods of construction and installation processes. This is due to the high responsibility of builders for the quality of construction products, because in the case of improper technology or design errors can endanger the lives of many people. Also, the implementation of innovative solutions is often associated with financial costs for research and technical and technological expertise, which leads to an increase in the cost of construction, and, consequently, reduce the profits of construction companies. This feature of the construction industry necessitates state support for its innovative development, creating conditions for its activation.

Increasing attention to environmental efficiency at all stages of the life cycle of construction products was considered by Y.D. Kim, H.S. Cha, K.R. Kim, D.W. Shin (2011), A. Zalejska-Jonsson, H. Lind, S. Hintze (2013), at the same time, their research concerned technical aspects and green building. Stages of promotion of green technologies on the market, problems of activation of innovative activity in the field of green building of separate countries were considered by A.P.C. Chan, A. Darko, A.O. Olanipekun, D.G.O. Manu, E.E. Ameyaw (2017; 2018; 2017), V.V. Dyma (2019). The issue of state support for the development of innovative green technologies in construction was considered by N.V. Stukalo, N.O. Krasnikova, I.O. Steblianko, N.P. Meshko (2018), etc. The development of "green" technologies in construction has its own features that must be taken into account while the state innovation policy forming.

The purpose of the article is to determine the current situation and directions for improving the state policy to support the development of green technologies in construction.

This research is expected to determine the main directions of implementation of green technologies in construction and to characterize the levers of state support for their implementation.

\section{Innovative green technologies in construction}

Green technologies in construction are aimed at the application of new architectural solutions, building materials, technological processes in order to reduce the use of non-renewable natural resources in the construction and operation of buildings; reduction of ecological load on the environment, including emissions of harmful substances during the product life cycle (from its construction to utilization).
The main areas of implementation of green technologies in construction are:

- obtaining and using energy from renewable and alternative non-combustible sources;

- increasing energy efficiency in buildings and lighting systems;

- reducing air and water pollution, soil restoration;

- eco-design;

- using new heat-insulating materials, coverings;

- recycling construction and household activities waste.

\section{Production and use of renewable and alternative energy sources in construction}

Nowadays, energy-efficient technologies make it possible to create energy-efficient buildings ("zeroenergy building" or a "nearly zero-energy building" (ZEB, NZEB) ). It is also possible to create "positive energy building" $(\mathrm{E}+, \mathrm{E}++)$, in which energy consumption is equivalent to, or even less than, its production.

The concept of construction of "positive energy buildings" has not yet been implemented in Ukraine, due to the lack of legal conditions for the formation of the electricity market. At the same time, such conditions have already been implemented in economically developed countries, which allow households to switch to individual home care for economic and environmental reasons. Their choice leans towards autonomy from public sources of electricity supplied by thermal power plants, nuclear reactors, which pollute the atmosphere. Many people choose full or partial autonomy, gradual disconnection from the common grid through a step-by-step installation of alternative energy-generating, energy-saving devices.

Energy-efficient buildings can generate energy from renewable energy sources directly in the house and store it. Energy from renewable sources is obtained from natural resources, such as: sunlight, water flows, wind, tides and geothermal heat, which are replenished naturally, as well as from biofuels: wood, vegetable oil, ethanol. A common and convenient way to generate energy is to use solar panels, which consist of a set of interconnected photovoltaic cells - photovoltaic modules, and energy generating device. Photovoltaic (PV) solar technologies are based on the use of special panels with cells consisting of two layers of different semiconductor materials (silicon), through which sunlight is converted into electricity, which is then transmitted to the grid, and at stand-alone 
stations by installation batteries have the ability to store electricity for further use. Solar power plants consist of solar modules connected in a single circuit, inverters and other equipment. Modern PV - panels have high energy efficiency and low degree of characteristics degradation. For example, the Talesun $260 \mathrm{~W}$ panel provides electric power up to $260 \mathrm{~W}$ and for the first 10 years its properties will remain at the level not less than $90 \%$. With sufficient lighting, excess electricity can be sent to the general grid ("green tariff"), or accumulate in home batteries. From them the house receives energy at peak loads of consumption, in the period of absence or insufficient solar radiation (winter, clouds). In addition to photovoltaic panels, wind power plants can also be used. But this should be facilitated by the location of the house and the characteristics of the reduced noise of the wind turbine. The generated electricity is used to cool the building in the warm season and for heating when it is cold.

Heat pumps are also often used for heating and cooling space. Depending on the location of the house, you can choose the most appropriate type of heat pump: "air-to-water", "water-to-water" or "ground-to-water". Air-to-air and air-to-water heat pumps are especially common and can be installed in almost any home. Dissipated heat in the ambient air is used for their work. Water-to-water and ground-to-water pumps can provide a heat output of up to $500 \mathrm{~kW}$. However, for small homes with low heat loss, such power is unnecessary. Producers of heat pumps, such as MIDEA, offer models available in variants with different power: $4,6,8$, $10,12,14$ and $16 \mathrm{~kW}$, which are more cost-effective for small homes. In addition to heating, heat pumps can provide the house with hot water. For hot water supply, it can be used solar collectors - vacuum or flat. Solar collectors effectively absorb the thermal component of sunlight. The combined use of photothermal collectors in combination with heat pumps allows to fully cover the needs for hot water throughout the year.

Depending on the climatic zones, local natural resources can be used. In particular, in Ukraine it is advisable to use thermal waters in Luhansk, Sumy, Poltava, Chernihiv and Kharkiv regions, but currently thermal waters deposits are preserved and not used. In the European countries, geothermal water is used for heating buildings, hot water supply, heating, agricultural (greenhouses) and industrial enterprises. In areas with uneven terrain, it is possible to build small-scale hydroelectric power plants, which can be installed on small rivers or mountain streams. It is possible to install biogas systems that produce electricity and heat in waste disposal.

For buildings of zero-energy consumption, in addition to renewable energy sources, special architectural design solutions, energy efficient materials are also used. In the construction of such houses, traditional building materials, such as brick, stone, concrete, are used to a much lesser extent. They are replaced by porous lightweight materials with high thermal insulation properties (basalt, mineral wool, foam glass and even straw).

\section{Policy to stimulate energy efficiency of buildings}

In Ukraine, stimulating the reduction of energy consumption is realized mainly by economic methods (high tariffs stimulate energy savings). Currently, the concept of innovative development of Ukraine declares support for energy-saving technologies. In practice, the mechanism of reimbursement of $20-35 \%$ of the loan amount for the purchase of energy-saving equipment, materials and boilers, which is carried out within the framework of the State Savings House Program, has been implemented so far. This program is implemented at the expense of the state budget, the maximum loan amount is about 2000 USD (Savings bank of Ukraine, 2020). It should be noted that although such compensations increase the environmental friendliness and energy efficiency of buildings, their mass sale is still impossible due to limited budget funds for these needs. Also in terms of intensifying the introduction of energy efficient technologies under the program "Enerhodim" in construction projects are being implemented for repair work to install energy efficient structures (plastic windows, new boilers, insulation, etc.), which are partially subsidized by the state, but the sum of these subsidies are currently quite limited.

High energy efficiency is also provided by automatic energy consumption control systems. All processes and operation of all systems can be controlled from the screen of a smartphone or computer. Intelligent analysis of data on consumption, adjustment of individual schedules of work of climatic and other equipment allow to improve energy efficiency and comfort essentially. 


\section{Reduction of air and water pollution}

The factor of environmental friendliness is also manifested in the water supply. In houses it is possible to use rain and melt water for household needs. It is carefully filtered and then used for washing, flushing in bathrooms, watering plants, etc. The system of technical use of water is sometimes closed. Various filtering equipment is used for this purpose. The main problems of implementation in this direction are the institutional and legal unpreparedness of Ukraine for the active implementation of innovations, mainly due to outdated housing and worn-out communal networks. To provide water supply through the condensing system, it is necessary to make changes in the drainage system, which requires coordination with the maintenance services.

\section{Eco-design in construction}

An eco-efficient building should be designed with the climate and location in mind to maximize the use of sunlight and protection from cold and strong winds. Due to the thoughtful design, most of the day the house should be lit by natural sunlight. To do this, architects must actively use passive and active methods of designing houses in different climatic conditions.

The architectural form of the house should fit harmoniously into the surrounding space, and its design should be developed taking into account meteorological and geological features of the area (wind rose, the flow of water during precipitation and melting snow) (Polishchuk, Lisitsa, 2013). This type of design is notable for taking into account the movement of wind and the flow of water during precipitation and melting snow. It is necessary that the building maintains a comfortable temperature and humidity throughout the year, and the air is saturated with oxygen at the required level. A large number of plants that fit organically into the interior play an important role in this. Greenhouses for growing vegetables can be placed on the roofs of houses. The house-garden is a separate branch of eco-design. The combination of landscaping and smart landscaping also significantly determines the energy consumption and ergonomics of buildings, such as the use of deciduous trees on the sunny side of the house and evergreen windbreaks on the cold, windy side. This makes homes "eco-compatible" as a part of the ecosystem.

The efficiency of heating and cooling can be increased by the right combination of adjacent buildings, such as a gazebo, greenhouse and surrounding houses.

But not only the exterior, but also the interior design is essential for creating an eco-efficient home. It concerns about:

- location of active rooms (living rooms, studios, offices, bedrooms) on the sunny side, and pantries, kitchens, dining rooms - on the cold side, which allows you to reasonably save heat and light;

- the location of active rooms on the upper floor above the warm lower rooms allow heat from the lower rooms to warm the upper floor;

- triple double-glazed windows, finishing with modern materials with low thermal conductivity help to reduce heat loss through windows and walls;

- heat radiating devices, predictably placed near the inner walls of the house, heaters, stoves, chimney installed on the inner wall of the house, as well as refrigerators can provide heat to neighboring rooms;

- windows on the roof or top floor in combination with an air filter in a cool basement can provide constant cooling in summer;

- well-lit hall with the main and secondary doors for gradual entry into the house can reduce heat loss when entering and exiting through the door.

Concern for the environment and energy efficiency is more than just a trend. They are a necessity for life. Therefore, architects and engineers are creating more and more alternative solutions for computer control of life support systems, linking all systems together. "Smart home" is a computer tracking system of control and automation, which uses a variety of devices and sensors, creating more comfort, efficiency, flexibility and security, simplifying the use of all home systems. Most energy efficiency issues can be addressed through network centralization of equipment.

\section{Utilization of construction waste, soil restoration}

Currently, blast furnace waste and construction waste are widely used for road construction, production of paving slabs, cement. Among construction waste, the largest share is made up of concrete and reinforced concrete $-52 \%$, stone materials $-32 \%$, asphalt waste $-8 \%$. In countries with limited mineral resources, approximately $90 \%$ of construction waste is recycled and reused. It is established that during the extraction of natural 
gravel 8 times more energy is consumed than when it is obtained from crushed old concrete. High-quality crushed stone of various fractions is obtained from the remains of reinforced concrete and brick structures during processing, which is then used in the manufacture of concrete for the construction of houses, roads, engineering infrastructure, railways, and landscaping works.

During the operation of buildings, active biowaste incineration systems are used to produce electricity and heat. The waste evaporates in a closed container, after it decomposes and forms combustible substances, which are used to generate electricity by a steam turbine. It is also possible to utilize passive biogas plants that use bacteria to gradually decompose waste into biogas, water and mineral fertilizers. When producing $1 \mathrm{~m}^{3}$ of biogas, you can get $4 \mathrm{~kg}$ of humus (fertilizers) and about 20 liters of water. Biogas plants burning $1 \mathrm{~m}^{3}$ of biogas produce $2.2 \mathrm{~kW} / \mathrm{h}$ of electricity and $4.1 \mathrm{~kW} / \mathrm{h}$ of thermal energy. In the future, the stepwise use of fertilizers allows you to benefit by growing different plants on the fertilized area with different minerals repeatedly. Combined gardening further expands this possibility by grouping plants that mutually maintain the mineral balance in the soil.

\section{Use of new heat-insulating materials, coverings}

Nowadays nanomaterials with unique properties are widely used in construction. They are a part of heat-insulating materials, paints, enamels, varnishes, etc. Thus, in particular, nanogels are transparent nanomaterials with high sound insulation and thermal insulation characteristics. They will be used in energy-saving roofing systems and decoration. Aerogel looks like foam or solid foam. It has an impressive low density, and many important properties, such as hardness, heat resistance, transparency, etc. Aerogel is able to withstand loads thousands of times its weight. Materials based on it can be widely used for thermal insulation of buildings, structures, equipment. Such heaters have a wide temperature range, which varies from -270 to $+385^{\circ} \mathrm{C}$. Aerogel is an absolutely safe material for the environment (including its utilization) and for the person, and it is also durable at operation.

Nanocoatings by their properties can replace the usual thermal insulation materials due to the simple application of waterproofing acrylic paints (instead of installing insulating fasteners and profiles). Such paints contain special nano- and micro-sized thermal protection components that reflect thermal radiation (reflection coefficient in the infrared spectrum -94\%), prevent heat transfer (thermal conductivity is $0.1 \mathrm{~W} /(\mathrm{m} \cdot \mathrm{K})$ ), provide significant energy savings in winter and in summer, they also have good performance properties (wearresistant, suitable for hardware application, have strong adhesion and flexibility of the coating, antifungal action, moisture resistance).

Prospects for the use of nanomaterials are also due to their energy efficiency, in particular due to the accumulation of solar energy. Nanolayers when used on windows and walls of houses will give facades a stylish look and at the same time will be able to work as solar batteries, considerably reducing energy expenses. A thin layer of innovative nanomaterials can be used to protect colored plastic windows from infrared (thermal) radiation, have special pigments that reflect up to $80 \%$ of infrared rays and prevent structures from overheating. As a result, it protects both the windows and the room from overheating, thereby extending the life of structures and reducing the cost of air conditioning.

\section{Conclusions}

The stateregulatorypolicy, in particularinnovation policy, policy to support R\&D, technology transfer, regulation of pricing policy, updating of regulations, including technological regulations, plays an extremely important role in stimulating the spread of green technologies in construction. Among the most important directions of state policy in construction there should be noted the following: the implementation of environmental and energy standards, quality standards for construction products, harmonized with international ones; stimulating consumer demand for environmentally friendly innovative solutions, including through "green" public procurement; setting fairer prices for ecosystem services; establishment of reasonable prices for energy resources, rejection of inefficient subsidies for fuel (gas, coal), incentives to implement the modern concept of product life cycle, which encourages the search for methods of product improvement at all stages of the cycle from production to disposal; development of financial mechanisms to support the demand for cleaner technologies and innovations (development of public-private partnerships, loan compensation, grants). 


\section{References:}

Kim, Y. D., Cha, H. S., Kim, K. R., \& Shin, D. W. (2011). Evaluation Method of Green Construction Technologies Using Integrated LCC and LCA Analysis. Korean Journal of Construction Engineering and Management, vol. 12, issue 3, pp. 91-100.

Zalejska-Jonsson, A., Lind, H., \& Hintze, S. (2013). Energy-Efficient Technologies and the Building's Saleable Floor Area: Bust or Boost for Highly-Efficient Green Construction? Buildings, vol. 3,pp. 570-587. Chan, A. P. Ch., Darko, A., \& Ameyaw, E. E. (2017). Strategies for Promoting Green Building Technologies Adoption in the Construction Industry-An International Study. Sustainability, vol. 9(6), p.969.

Chan, A. P. Ch., Darko, A., Olanipekun, A. O., \& Ameyaw, E. E. (2018). Critical barriers to green building technologies adoption in developing countries: The case of Ghana. Journal of Cleaner Production, vol. 172, pp. 1067-1079.

Darko, A., Chan, A. P.C., Manu, D. G. O., \& Ameyaw, E.E. (2017). Drivers for implementing green building technologies: An international survey of experts. Journal of Cleaner Production, vol. 145, pp. 386-394.

Dyma, V. V. (2019). Mizhnarodnyi dosvid zastosuvannia stymuliuiuchykh mekhanizmiv rozvytku «zelenoi» ekonomiky [International experience of application of stimulating mechanisms of development of "green" economy]. Scientific notes of TNU named after VI Vernadsky. Series: Public Administration, vol. 30(69), no. 6.

Stukalo, N. V., Krasnikova, N. O., Steblianko, I. O., \& Meshko, N. P. (2018). «Zelena» ekonomika: vid hlobalnoi kontseptsii do realii mistsevoho rozvytku ["Green" economy: from the global concept to the realities of local development]. Dnieper: Serednyak T.K.

Savings bank of Ukraine (2020). The The Savings House program. Available at: https://www.oschadbank.ua/ ua/private/loans/oschad_home (accessed: 20 February 2020).

Polishchuk, A. A., \& Lisitsa, P. S. (2013). Stroitelstvo avtonomnykh energoeffektivnykh domov (s ispolzovaniem solomennykh blokov) [Construction of self-contained energy efficient houses (using straw blocks)]. Bulletin of the Donbass National Academy of Education and Architecture, vol. 3(101), pp. 130-133. 